\title{
Sprawozdanie z ogólnopolskiej konferencji naukowej „Prawny model zatrudnienia nauczyciela akademickiego", Poznań, 15 stycznia 2016 r.
}

W dniu 15 stycznia 2016 r. na Wydziale Prawa i Administracji Uniwersytetu im. Adama Mickiewicza w Poznaniu odbyła się ogólnopolska konferencja naukowa "Prawny model zatrudnienia nauczyciela akademickiego". Organizatorami konferencji byli Dziekan Wydziału Prawa i Administracji w Poznaniu prof. dr hab. Roman Budzinowski oraz Rektor Uniwersytetu im. Adama Mickiewicza prof. dr hab. Bronisław Marciniak. Patronat honorowy objął prof. dr hab. Wiesław Banyś, Przewodniczący Konferencji Rektorów Akademickich Szkół Polskich.

Konferencja zgromadziła 150 przedstawicieli nauki i praktyki prawa pracy. Jako pierwsza zebranych powitała dr hab. Anna Musiała, która stwierdziła, że zorganizowanie konferencji zostało podyktowane głęboka potrzebą przedyskutowania i w konsekwencji wysunięcia spójnej i kompleksowej propozycji prawnej regulacji dotyczącej zatrudnienia nauczyciela akademickiego. Podkreśliła konieczność takiego unormowania, które odpowie wyzwaniom współczesności, a jednocześnie stworzy optymalne uwarunkowania dla misji, jaką niewątpliwie jest praca nauczyciela akademickiego. Następnie głos zabrał rektor UAM, który powitał uczestników, wskazał na ważkość podjętego zagadnienia i potrzebę wypracowania wizji modelu prawnego zatrudnienia nauczyciela akademickiego.

Jako kolejny wystąpił dziekan Wydziału Prawa i Administracji, który witając gości, stwierdził, że temat konferencji jest niezwykle interesujący dla pracowników uczelni wyższych. Wyraził osobistą satysfakcję z powodu zgromadzenia na konferencji tak licznego grona osób zainteresowanych, związanych z tematyką nie tylko w związku z pełnioną funkcją, ale również ze względu na swoje zainteresowania badawcze.

Program konferencji przewidywał dwie części. W pierwszej, teoretycznej zostały przedyskutowane problemy unormowania pracy nauczyciela akademickiego w świetle obowiązujących przepisów. Referaty wygłosili: prof. Krzysztof Baran (Uniwersytet Jagielloński), prof. Jakub Stelina (Uniwersytet Gdański), prof. Zbigniew Góral (Uniwersytet Łódzki), dr hab. Monika Lewandowicz-Machnikowska (Uniwersytet Wrocławski), dr hab. Krzysztof Walczak (Uniwersytet Warszawski), dr hab. Anna Musiała (Uniwersytet im. Adama Mickiewicza w Poznaniu), dr Aleksandra Bocheńska (Uniwersytet im. Adama Mickiewicza w Poznaniu). Druga część miała zaś charakter panelowy. Wystąpili w niej: przewodniczący Rady Głównej 
Nauki i Szkolnictwa Wyższego prof. Jerzy Woźnicki, prorektor ds. kadry i rozwoju uczelni UAM prof. Andrzej Lesicki, prorektor ds. kształcenia UAM prof. Krzysztof Krasowski, zastępca dyrektora Departamentu Szkolnictwa Wyższego i Kontroli w Ministerstwie Nauki i Szkolnictwa Wyższego dr Ewa Trojanowska, dziekan Wydziału Prawa i Administracji Uniwersytetu Gdańskiego prof. Jakub Stelina, a więc osoby na co dzień rozwiązujące problemy prawnej regulacji pracy nauczyciela akademickiego, a także dr hab. Anna Kosut.

Pierwszą część konferencji rozpoczął prof. dr hab. Krzysztof Baran wystąpieniem Kontrowersje wokół zatrudniania pracowników w szkolnictwie wyższym, który zwrócił uwage na wieloaspektowość akademickiego prawa pracy. Odniósł się również do problematyki rozwiązywania stosunku pracy nauczyciela akademickiego z powodu upływu okresu zajmowania stanowiska i wskazał na konieczność dalszych prac w zakresie dodatkowego zatrudnienia nauczyciela akademickiego. W kolejnym wystąpieniu Problematyka ocen okresowych nauczycieli akademickich prof. dr hab. Zbigniew Góral wskazał na cztery funkcje, jakie pełni ocena okresowa nauczyciela akademickiego, a mianowicie: korekcyjna, kadrowa, czyli jakościowa, i eliminacyjna, oraz szczegółowo omówił każdą z nich. Podkreślił konieczność zmian w zakresie sposobu oceny pracy nauczycieli akademickich. Prof. dr hab. Jakub Stelina w referacie Uwagi ogólne na temat modelu zatrudnienia i kariery naukowej nauczycieli akademickich odniósł się do podstawy zatrudnienia nauczyciela akademickiego również w ujęciu historycznym. Stwierdził, że podstawy prawne zatrudnienia nauczyciela akademickiego wymagają uporządkowania. Dr hab. Monika Lewandowicz-Machnikowska poświęciła swoje wystąpienie tematyce zagrożeń zawodowych mających miejsce w pracy nauczycieli akademickich i związanych z nimi praw i obowiązków stron stosunku pracy. Prelegentka przedstawiła czynniki szkodliwe występujące w środowisku pracy nauczycieli akademickich i wskazała, w jaki sposób prawny model zatrudnienia nauczycieli akademickich naraża ich na ryzyko wypalenia zawodowego. Dr hab. Krzysztof Walczak w referacie Wynagrodzenia nauczycieli akademickich i metody motywacyjne podkreślił między innymi znaczenie wartościowania stanowisk pracy nauczycieli akademickich przy ustalaniu taryfikatora wynagrodzeń. Kolejna prelekcja przygotowana przez dr Aleksandrę Bocheńską dotyczyła dodatkowego zatrudnienia nauczyciela akademickiego. Referentka przedstawiła ewolucję regulacji prawnej w zakresie limitowania dodatkowego zatrudnienia nauczyciela akademickiego oraz przedstawiła kontrowersje pojawiające się w związku z obecnie przyjętymi rozwiązaniami. Pierwszą część konferencji zakończyło wystąpienie dr hab. Anny Musiały, która wygłosiła referat Charakter prawny zatrudnienia doktoranta. Prelegentka podkreśliła konieczność wypracowania modelu zatrudnienia doktorantów oraz jednoznacznego określenia ich statusu prawnego.

Prowadzenie drugiej części konferencji objął prof. dr hab. Krzysztof Krasowski, który był moderatorem panelu dyskusyjnego Prawny model zatrudnienia nauczyciela akademickiego a praktyka. Kierunki zmian. Dyskutanci skupili się między innymi na zagadnieniach związanych z modelem kariery naukowej, odpowiadali na pytania uczestników konferencji dotyczących umów cywilnoprawnych w szkolnictwie wyższym i praw autorskich.

Prof. dr hab. Jerzy Woźnicki wskazał na konieczność uelastycznienia polityki kadrowej uczelni w zależności od reprezentowanej dyscypliny naukowej oraz siły 
danego ośrodka naukowego. Przywołał on stanowisko ministra nauki i szkolnictwa wyższego dr. Jarosława Gowina, który uznaje potrzebę deregulacji systemu szkolnictwa wyższego i nieprzyjmowania szybkiej ścieżki legislacyjnej, lecz skoncentrowania się na pracy w zespole ministerialno-środowiskowym i stopniowym odbiurokratyzowaniu procedur. W toku dyskusji wyłonił się również problem celowości utrzymania postępowania habilitacyjnego. Dr Ewa Trojanowska zauważyła, że jest to stały element wszelkich rozważań dotyczących modelu kariery naukowej. Podjęła również problem postępowania dyscyplinarnego i podkreśliła wyraźny wzrost liczby spraw dyscyplinarnych związanych z szeroko pojętą nierzetelności naukową. Przedstawiła uczestnikom dane statystyczne ( $w$ roku 2012 - 12 postępowań, w roku 2015 - 200 spraw dyscyplinarnych prowadzonych przed komisją dyscyplinarną ds. nauczycieli akademickich przy RGSW). W dalszej kolejności wskazała na potrzebę szerszej dyskusji dotyczącej etyki zawodowej nauczyciela akademickiego. Prof. dr hab. Andrzej Lesicki zaakcentował negatywne, jego zdaniem, zjawisko nadmiernej koncentracji na wskaźnikach bibliometrycznych oraz zamykanie się w ocenach parametrycznych. Prof. dr hab. Krzysztof Krasowski zwrócił uwagę na konieczność kontynuowania dyskusji nad przyszłością i charakterem studiów doktoranckich. Dr Marcin Czechowski, komentując referat dr hab. Anny Musiały, opowiedział się za poprawą sytuacji materialnej doktorantów oraz ustabilizowaniem ich pozycji na uczelni. Dr hab. Anna Kosut podjęła temat tzw. szczególnej ochrony stosunku pracy nauczyciela akademickiego. Wskazała na brak jednoznacznej regulacji w pragmatyce zawodowej, co prowadzi do nieuzasadnionego uprzywilejowania pracowników umownych w stosunku do nauczycieli akademickich zatrudnionych na podstawie mianowania.

Uczestnicy konferencji wyrazili głębokie przekonanie, że dalsza dyskusja nad prawnym modelem zatrudnienia nauczyciela akademickiego zarówno $\mathrm{w}$ formie środowiskowych seminariów, jak i konferencji naukowych jest konieczna.

Prof. Bronisław Marciniak podziękował wszystkim uczestnikom spotkania za udział, szczególne wyrazy wdzięczności skierował do organizatorów konferencji.

W niniejszym sprawozdaniu zaprezentowano jedynie główne tezy wystąień i zakreślono przebieg konferencji w skrótowej formie. Wygłoszone referaty, a także dyskusja panelowa zostaną zebrane w publikacji pokonferencyjnej, której wydanie planowane jest na połowę 2016 roku.

Aleksandra Bocheńska

DOI: 10.14746/spp.2016.1.13.14 